\title{
Adequate Financing And Agricultural Production: Response To New Generation Agriculture In Cameroon
}

\author{
Mbu Daniel Tambi, Wirbam Mary-Juliet Bime \\ Department of Agricultural Economics; University of Dschang, Cameroon, \\ Department of Agribusiness Technology; University of Bamenda \\ E-mail: tambi2015@yahoo.co.uk, mimeliet001@yahoo.com
}

\begin{abstract}
Food insecurity, malnutrition and hunger are persistent within the urban and rural areas in Cameroon resulting from inadequate development policy approaches. As a step to solve this problem, our study seeks principally to: evaluate the impact of adequate financing on agricultural production. Use is made of control function modeling. Empirical results are based on 2007 household consumption survey and statistics from Ministry of Agriculture. The result shows that adequate financing is strongly correlated with agricultural production, while results by type and nature of agricultural credit show that personal financing, bank and micro-financial institution, family and partners, friends and tontines and institutional support is increasing agricultural production. Further, subsidies in kind contribute more in augmenting agricultural production as compared to subsidies in cash. These results have implications for addressing the food security problem and poverty reduction in terms of improving agricultural productivity through adequate financing and subsidies in kind and income growth in this period of economic emergence.
\end{abstract}

Keywords: Quantifying, Adequate Financing, New Generation Agriculture, Cameroon

\section{A. INTRODUCTION}

For more than a decade, agriculture in Cameroon contributes more than 44 percent to GDP and it's the principal occupation of over 56 percent of the economically active population, however only about 15.4 percent of the land is arable. Apart from some few mechanized industrial exploitations, agriculture in Cameroon is essentially traditional with subsistence, manual work is usually very arduous, the cultivated surface area is also reduced, and yields are low and therefore insufficient to meet both domestic and external demand for food. The decision makers are forced to import large quantities of cereals (rice, maize) to fill the gap in production, feed its population and meet the demands of the brewing industries, so there is a need to modernized Cameroon's agriculture, so as to increase the productivity of small farmers and encourage the emergence of "second generation" production units; that is large and medium size companies. This is imperative because agriculture act as a multiplier effect in the global chain of production and in the acceleration of macro-economic aggregates.

Cameroon is an agricultural country with over 13 million people living in rural areas representing approximately about 70 percent of the total population. As intimated by ministry of agriculture and rural development (MINADER) (2007) food production has not follow the rapid demographic increase, especially in the urban areas, hence food security has to be assured by an increase in the production of food stuff and other crops which could substitute importations. To meet this need, MINADER has as an objective for a sector's development strategy, set a target in 2015 to train 30.000 farmers in domains such as extension agents, agricultural advisers and farmers' organizations per year. MINADER has 35 centers for agricultural training (24 are rural training centers and 11 are centers for the training of young farmers) (MINADER, 2007).

As geographically positioned, Cameroon is one of the most diversified countries in Sub-Saharan Africa (SSA) in terms of agro-ecology, stretching from a semi-arid sudan-sahelian zone in the far north to tropical rain forest zones in the centre, south and east regions. In terms of statistics, most rural households (97 percent) are engaged in crop production and 72 percent combine stock rearing with farming. Peasant farming accounts for 40 percent of export crop production and 72 percent of food crops and employs about 60 percent of the active population. The primary sector is the main stay of Cameroon's economy. Primary sector exports account for about 55 percent of non-oil export earnings. The sector's GDP was estimated to be a little over 44 percent in 2006, with the large domination of crop and forest products (ADB, 2010).

Following GOC (2011), land use is as follows: arable land 13 percent, permanent crops 2 percent, permanent pastures 4 percent, forests and wood land 78 percent (rain-forest 
represents 40 percent of total land use), and others 3 percent. The main environmental issues are: deforestation; overgrazing; desertification; poaching and over fishing. Arable land is estimated at 7.2 million hectares, but only 1.8 million hectares are effectively cultivated. The most important cash crops are cocoa, coffee, cotton, bananas, rubber, palm oil and kernels, tobacco, tea, pineapples and peanut. According to Business Cameroon (2006), Cameroon is among the world's largest cocoa producers with 130000 tons of cocoa beans produced in 2004 and over 200,000 tons produced in 2009. The main food crops are plantains, cassava, corn, millet, yam, cocoyam, potatoes and beans. Estimated production of food crops in 2004 was as follows: sugarcane 1450000 tons; cassava 1 950000 tons; sorghum 550000 tons; corn 750 000 tons; millet 50000 tons; yams 265000 tons; sweet potatoes 175000 tons; potatoes 135 000 tons; dry beans 95000 tons; and rice 62000 tons (GOC, 2011).

As a motivation for using rice production, a study conducted by the ACDIC in 2006, showed that Cameroonians, like rice and that rice is the most popular and most consumed foodstuff in the country. In towns like Douala, out of every four households three eat rice at least thrice a week; this shows that there is a high local demand for the commodity. According to the 2007 household consumption survey, average rice consumption per head in Cameroon in 2007 was worth $22.36 \$$ in urban areas for towns with more than 50,000 inhabitants; $11.634 \$$ in rural areas; the national average was $15.414 \$$. Taking an average price of $0.6 \$$ per kilogram, this consumption would be around $37.3 \mathrm{~kg}$ in urban areas, $19.4 \mathrm{~kg}$ in rural areas and $25.7 \mathrm{~kg}$ per inhabitant for the national average (FAO, 2006). Rice in Cameroon is produced largely by subsistence farmers. Unlike other cereals, rice is produced largely for human consumption, but what is produced in Cameroon is unable to meet growing national demand (IRRI, 2007). As sited by Molua (2010), Cameroon's milled rice production increased from 37,000 to 51,000 metric tons between 1997 and 2006. In the same period, the domestic consumption increased from 199,000 to 433,000 metric tons showing that local consumption is more than production; an unpleasant situation. According to Business Cameroon, Cameroon spent $0.1934 \$$ billion on rice importation in 2012. Since 2004, the demand for rice has kept rising and supply of locally produced rice dwindling.

In all these production statistics, food insecurity, malnutrition and hunger are persistent within the urban and rural areas in Cameroon. This situation is not due to the lack of food, but to poor systems for regulating the access to food resulting from inadequate development policy approaches and use of the available funds. Development policies are not sensitive to the nature of financing, protection and promotion of the cultivation and consumption of local products. Significant investments in giant agro industrial projects have failed, wasting huge financial and material resources and leaving thousands of actors in the chain frustrated. Bad governance in the drawing up and implementation of rural development projects makes many projects best bets for government functionaries to the detriment of the producers and other actors in the chain. To fill this gap, we have as objectives to: evaluate the impact of adequate financing on agricultural production, explore the determinants of adequate financing in second-generation agriculture and examine adequate financing effect by type and nature of agricultural credit.

\section{Concept of Adequate Financing}

Adequate financing is the act of using personal finance or credit received from either banks or micro financial institutions, family/partners, friends/tontines, institutions support and subsidies in both cash and kind effectively for the production of agricultural products. In the Cameroon Demographic and Health Survey data set, this variable is coded as "s1410" to mean loan mainly used for generating revenue. We consider this as credit effectively invested in agriculture to realized production, thus adequate financing is the actual amount of input (in cash and in kind) that farmers effectively used to realize agricultural production. Much money or credit can be given to farmers but it's the one actually use for mechanization, seed planting, payment of labourers, fertilizers and the application of other inputs that we consider as adequate financing.

Agriculture is a dominant sector of our economy and credit/adequate financing plays an important role in increasing agricultural production. Availability and access to adequate, timely and low cost credit from institutional sources is of great importance especially to small and marginal farmers. Along with other inputs, adequate financing is essential for establishing sustainable and profitable farming systems. Most of the farmers in Cameroon are small producers engaged in agricultural activities in areas of widely varying potential. Experience has shown that easy access to financial services at affordable cost positively affects the productivity, asset formation, income and food security of the rural poor. The major concern of the Government is therefore; to bring 
all the farmer households within the banking fold and promote complete financial inclusion.

The concept of new generation agriculture in Cameroon, is used to mean advanced agriculture, which is the absolute transformation of the agricultural sector via mechanization, market oriented agriculture, practice of value chain agriculture, good seeds, improved varieties and irrigation in an efforts to triple crop yields for consumption and the market. Apart from land reforms being prepared to make land for plantation agriculture more accessible, the setting up of an agricultural land development and management agency and the design of the soil aptitude map are also envisaged. Several other landmark projects intended to transform the agricultural sector, including the imminent general agricultural census - a tool for better decision-taking in the sector and efforts to resort more and more to irrigation techniques and make high-yield seeds more available are also envisage in the pipeline.

To obtain the new agricultural objectives, the government embarked on the following projects: establishment of an agricultural tractor assembly plant in Ebolowa (already operational), the construction of 700,000-ton fertilizer plant (underway), the rehabilitation of seed farms, the strengthening of funding mechanisms for rural activities via the creation of a Farmer's Bank and the SME/SMI Bank, a trainers training workshop in the Binguela Practicing Farming School began in 2013. Further, the government signed many conventions, to begin with: agricultural engineers from the Brazil's Federal Institute of Education, Science and Technology are currently drilling Cameroonian agricultural stakeholders on modern farming techniques; and Cameroon and China signed four Cooperation agreements including that relating to the funding of the construction and equipment project of a Technical Agricultural High School of Yabassi, worth about 12.96 billion US dollars.

\section{Literature Review}

Following the GOC (2011), microfinance is an important pillar of the poverty reduction strategy paper prepared by the Cameroon Government. To facilitate access to appropriate financial services for the marginalized, the government opted to encourage bottom-up grassroots initiatives. Accordingly, it published a microfinance national policy statement, whose strategy is to: (i) improve interaction between microfinance institutions and between such institutions and their local environment; (ii) create and develop an administrative, legal and judicial framework that is conducive to the development of microfinance institutions; (iii) promote professionalism and transparency in the management of microfinance institutions; (iv) consolidate and extend the harmonious development of microfinance institutions all over the national territory; (v) encourage partnership agreements between development projects, NGOs, microfinance institutions and the banking system; and (vi) bring together microfinance institutions and socio-professional farmers organizations.

Microfinance are generally absent in rural Cameroon, thus, given its importance in the economy, the rural sector has enormous spillover effects on the other sectors and so contributes to export diversification, food insecurity, job creation and poverty reduction (GOC, 2011). The major constraints on agricultural rural sector development are: (i) the low level of training for farmers and the limited number of training facilities; (ii) limited private sector participation; (iii) the insufficiency and poor state of rural infrastructure; (iv) limited access to farm inputs and products; (v) insufficient financing; (vi) seed production and marketing difficulties; (vii) the high incidence of diseases and pests; (viii) limited access to land and land tenure insecurity; (xi) poor consideration of the criterion of competence in recruiting management staff for the sector; (x) over-centralization of Government services; and (xi) complex and unwieldy administrative procedures that cause delays and sometimes lead to corruption (NIS, 2002).

Considering all these, FAO (2006) noted that the average annual rate of variation in the growth of food production was 3.4 percent from $2000-2003$ to $2005-2007$. This rate inched up to 7.4 percent between 2005/2007 and 2012-2014, due to high demand driven by rapid urbanization and neighbouring countries. As underscore by the food and agricultural organization of the United Nations organization, the following results were obtained for three major products in 2007-2014: (i) sorghum: (12 percent of production, 1.9 percent of yield increase); (ii) maize: (12 percent of production, 2 percent of surface area increase); (iii) cassava (11 percent of production and 3 percent of surface area increase). Food production benefitted from the return of farmers to this sector when they suffered a fall in their purchasing power. Output therefore increased, although it still does not satisfy local food needs and also has to compete with subsidized foreign products. Meanwhile, the population presents a rate that has declined from 2.7 to 2.2 over the period. 


\section{B. METHODOLOGY}

We used a modified version of agricultural production function model as originally proposed by Rosenzweig and Schultz (1983). In a given production function, agriculture is a function of factors such as size of the farm, rainfall variation, geographical location of household and content of the soil at the time of planting. In practice, money prices are not observed for many inputs into agricultural production functions, such as use of subsidies in kind. If the time cost of using these inputs is large, then measures of institutional, banks and micro financial institutions are part of the full price of service and may serve to identify the agricultural inputs, Cebu Study Team (1992) provide examples of this approach by estimating production functions.

In some agriculture literature, it is assumed that the production function is static so that current output is a function of only current inputs. However, many human capital and farm input variables we are concerned about are stocks, not flows. For instance, many farm variables, such as soil fertility, fertilizer or manure are cumulative measures that depend on inputs in past periods and possibly on past farm outcomes as well. In fact, adopting from Grossman's (1972a) seminal paper on the demand for health treats health as a capital stock, which depends on past values and current inputs, more so in the Grossman's model, the demand for agricultural productivity is for investment and consumption purposes (Ajakaiye and Mwabu, 2007). In the spirit of this framework, agricultural output yields direct utility to an individual and also increases labour income through adequate financing so that more is produced to compensate work effort and alleviate poverty.

\section{Econometric Issues}

As can be expected, in the agricultural sector adequate financing ( $A F$ ) is generally belief to be associated with increase agricultural production ( $A \operatorname{Pr}_{\text {sga }}$ ) thus $A F$ and $A \operatorname{Pr}_{\text {sga }}$ can be jointly estimated though each has its own interpretation. It has been revealed in most agricultural literature that agricultural inputs such as human labour, fertilizer, seeds, mechanization... and environmental characteristics such as soil content, climate (temperature and rainfall variability) are important components of household agricultural production, food security and poverty reduction. It shapes the present, intermediate and future human capital as well as livelihood opportunities for better standards of living. Thus, an initial good and unpolluted soil does not only affect the biological bacterial of the soil, household growth potential, household nutrition and health in later years of life; but also engenders potential household revenue, increase savings firstly due to sales from agricultural produce and secondly from medical expenditures due to good health by virtue of nutrition. Indirectly, good health releases extratime to adult household members to take more advantage of labour market opportunities, as well as household children's capacity to study and secure better future standards of living.

From above, we can confidently note that $A F$ is an important input in the agricultural production function of the household registering principally both direct and indirect effects on household income through increase productivity in the value chain agriculture, much food for consumption, good health due to better nutrition, peace of mind, potential savings and general poverty alleviation. The causal link of adequate financing and household secondgeneration agriculture can be depicted by the following equations:

$\left\lfloor A \operatorname{Pr}_{s g a}=w_{1} \pi_{b}+\sum_{j} v_{j} A F_{j}+\varepsilon_{1} j=1 \ldots . .3\right\rfloor$

$$
A F_{j}=w_{2} \pi_{A F j}+w_{2} \Omega_{A F j}+\varepsilon_{2 j}
$$

$$
A \operatorname{Pr}_{s g a}=w_{1} \pi+v A F+\gamma_{1} \hat{\varepsilon}_{2}+\gamma_{2}\left(\hat{\varepsilon}_{2} * A F\right)+\zeta
$$

Where by $A \mathrm{Pr}_{\text {sga }}$ is household agricultural production in second-generation agriculture indicator; $A F$ is adequate financing mostly obtained from (personal finance, credit from banks and micro financial institutions,

institutional support...). The $w_{1}$ is a vector of exogenous covariates (ownership of land asset, size of rice farm, rainfall variation, geographical location of households...); $v$ is the parameter of the potentially endogenous explanatory variable $(A F)$ in the second-generation agricultural function, $\pi_{b}$ is the vector of parameters to be estimated; ${ }^{\varepsilon_{1}}$ is the error term that captures both random effects and unobservable variables. $w_{2}$ is a vector of exogenous instrumental variables affecting adequate financing ( $A F$ ) but have no direct influence on agricultural production; $\pi_{A F j}$ and $\Omega_{A F j}$ are vectors of parameters of exogenous explanatory variables in the reduced form adequate financing function to be estimated; $\boldsymbol{\varepsilon}_{2 j}$ is the error term that 
captures both the random effects and other relevant but unobservable characteristics or complementary inputs; $\hat{\varepsilon}_{2}$ is fitted residual of $A F$, derived from the reduced form linear probability model of adequate financing (equation 2); $\hat{\varepsilon}_{2}{ }^{*} A F$ is the interaction of the fitted adequate financing (credit) residual with the actual value of financing status; $\zeta$ is a composite error term comprising $\varepsilon_{1}$ and the unpredicted part of $\varepsilon_{2}$, under the assumption that $E(\zeta)=0$ and $\pi, v, \lambda, \gamma$ are parameters to be estimated.

\section{Structural Equation (1)}

Owing to the issues define above; equation 1 is our structural equation of interest. The equation econometrically link adequate financing (that principally include finance from personal finance, credit from banks and micro financial institutions, aid from family and partners, friends and tontines, institutional support, subsidies in cash and subsidies in kind) to second-generation agricultural function. Following equation 1 therefore, the estimation of the parameter $v_{j}$ would show the effect of adequate financing on household secondgeneration agricultural production function. Thus, equation 1 is the structural equation of interest that is the agricultural production technology whose parameters are to be estimated.

\section{Reduced Form Equation (2)}

Following Wooldridge (2002) and Mwabu (2009) the reduced form of adequate financing generating the agricultural production estimation strategy can take the form of equation 2. Hence, equation 2 is the linear projection of the potentially endogenous variable ( $A F$ ), on all the exogenous variables. Given that $A F$ and $A \operatorname{Pr}_{\text {sga }}$ are jointly determined in association to the problem of variation omission in demographic and health survey or bias in time of collection or treatment of the variables, the problem of endogeneity may arise. Based on equation 1 and 2, to resolved this problem, we employ instrumental variable estimates (IV 2SLS, see table 3, column 3). For this to be made possible we use as endogenous instrument; professional association network and availability of financial institution. Thus, the instrumental variables (2SLS) model based on equations 1 and 2 will be estimated for the determinants of asset endowments using the econometric software STATA 14.0.

In the recent literature, the endogenous explanatory variables are commonly referred to as "treatment variables". This terminology stresses the fact that the most credible way to measure the effect of an endogenous variable on the outcome variable of interest (i.e. to identify treatment effect) is to vary the endogenous variable experimentally. In an experimental setting, this variation is achieved through a random assignment of units of study into treatment and control groups. The word "treatment" is used to indicate that a section of the study sample is "treated" (its characteristic of interest, such as adequate financing, is varied exogenously). Since this variation occurs when other causal factors are held constant, it is possible to identify the effect of the characteristic on outcome variable of interest ( $A F$ ). In the absence of an experiment, such a variation is achieved through an econometric procedure, with the aid of a structural model (see, Strauss and Thomas, 1998).

Verifying the impact of professional association network and availability of financial institution on adequate financing, professional network facilitate access to credit, most donors in the 21 st century have adopted a new system of giving grants to groups rather than individuals. This explains why most farmers constitute themselves in to small groups such as common initiative group (CIG), associations and cooperatives. It's also important to note that when farmers come together, they work effectively in symbiosis and easily develop themselves than otherwise. The ministry of agriculture and rural development in Cameroon has as a role to assist mostly groups, hence there is a strong correlation between adequate financing and professional network. In the same way, the more there are financial institutions in a particular place the more it's easier to take credit, given the interest rate attached to each loan, many farmers turn to adequately invest the credit in their farms.

Mwabu (2009) intimated that an instrument is relevant if its effect on a potentially endogenous explanatory variable is statistically significant. Second, an instrument is strong, if the size of its effect is 'large'. Finally, the instrument is exogenous if it is uncorrelated with the structural error term. An instrumental variable that meets all these requirements is a valid instrument, but often very difficult to find (Rivers and Vuong, 1988; Bound et al., 1995). 


\section{Control Function Specification (3)}

As noted by Garen (1984), to take care of potential endogeneity bias and non-linear interactions of unobservable variables with the observed regressors specified in the secondgeneration agricultural production function regressors simultaneously, equation 1 can be upgraded to equation 3 . This control function specification takes the form as seen in equation 3. Exclusion restrictions are imposed on equation (3) because the set of instruments for household adequate financing status is absent

from the equation. The terms $\hat{\varepsilon}_{2}$ and $\left(\hat{\varepsilon}_{2} * A F\right)$ in equation 3 are the control function variables because they control for the effects of unobserved factors that would otherwise contaminate the estimates of structural parameters. The reduced form

financing residual, $\hat{\varepsilon}_{2}$ serves as the control for unobservable variables that correlate with $A F$. In particular, if an unobserved variable is linear

in $\hat{\varepsilon}_{2}$, it is only the constant term that is affected by the unobservable and the instrumental variable $(I V)$ estimates of equation 3 are consistent even without the inclusion of the interaction term.

As intimated in Wooldridge (1997), the IV estimates of equation 3 are unbiased and consistent only when the following conditions hold: (1) the expected value of the interaction between adequate financing and its residual $\left(\hat{\varepsilon}_{2} * A F\right)$ is zero, or the expectation of the interaction between financing and its fitted residual is linear, and (2) there is no sample selection problem. However, if the correlation is non-linear, then the control function approach is required and the inclusion of the interaction term, $\left(\hat{\varepsilon}_{2} * A F\right)$, equation 3 purges the estimated coefficients of the effects of unobservable variables (Card, 2001).

When the control function variables are generated via the reduced form linear probability model of demand for agricultural services, which corresponds to the first-stage estimates of the IV, Ordinary Least Squares (OLS) regression that includes both the structural parameters and the control function variables will purge the structural estimates of potential simultaneity bias and unobserved heterogeneity.

\section{Data Presentation}

We used the 2007 household consumption survey (HCS) to analyze our data in STATA 14.0. Regarding the case of Cameroon, the Ministry of Economic Affairs, Programming and Regional Development is the executing agency of the HCS and it is the National Institute of Statistics that collects the data. The HCS was aimed at a national representative sample of about 11391 households, with women of reproductive age, alive and living within the selected zones of sample as well as a sub sample of about 50 percent of households for the men. The results of these surveys were presented for Cameroon, other towns, urban and rural zones and each of the 12 areas of study (constituting 10 regions plus Douala and Yaounde. All the members of households drawn are registered in household questionnaire.

Our variable of interest is agricultural production captured in this study by $\log$ of rice production in tons. The principal endogenous variable is adequate financing captured as credit effectively used in agricultural production; the instruments for endogenous variables are professional association network and financial institution availability. The exogenous demographics are: mother's education in years of schooling, mother's age, mother works' in agricultural sector, male household head, household size, paternal occupation, ownership of land asset, earnings from agricultural activity, paternal education in years of schooling, paternal age, social status, size of rice farm, rainfall variations and geographical location of household. Variables such as rice production, , size of rice farm and rainfall characteristics were imported from the department of statistics of Ministry of Agriculture and Rural Development.

\section{Empirical Results Sample Descriptive Statistics}

From the weighted sample statistics table, about 7.76 percent of tons of rice is produce every year in Cameroon with a regional minimum of 3.4 tons and a maximum of 11.6 tons especially in the northern regions of Cameroon as compared to other staple food crops in Cameroon. Generally, rice is a staple food in Cameroon consumed by almost everybody, everywhere and at all times. Most Cameroonian households have rice on the menu at least twice every week (GOC, 2013). Amongst the most important cash crops; rice is the most staple food crop grown in Cameroon (Molua, 2010). However, only 1 percent of farmland is use as cultivable farms for rice production, this percentage is relatively so small for a crop that is widely consume in Cameroon and by most of the citizens. Further, only I percent of farmers own land asset imposing 
additional constraint in the development and increase of agricultural production in Cameroon.

Upon all financing given to farmers in Cameroon, only 4.2 percent may be considered as adequate financing. Agricultural financing or aid can either be in cash or in kind, implying that the farmers in position of these may decide either to or not to use what they received as credit. In this perspective, only 3.7 percent are involved in professional association network, 72 percent of financial institutions available in Cameroon are concern with agricultural financing. The earnings of farmers is up to 96.6 percent meaning that most of the workers involve in agriculture are fulltime and so is their earnings with only 3.4 percent coming from other activities such as business.

About 62 percent of women are involve in agricultural activities, meaning that more women are implicated in farming practice while about 59.3 percent of these women are educated with a minimum age of 15 years and maximum 49 years old. This is an active population strong enough to increase agricultural production in Cameroon. Geographically, about 39 percent of the households live in urban centers with 53 percent non poor homes with father's age ranging from 17 to 98 years all in agricultural production respectively. Many have average household size that has sufficient labour to take care of the household agricultural activities. The rain fall variation has averagely been favourable for the production of agricultural crops. Most of the household heads are male headed with a low percentage of education but fully involve in agricultural production and other primary activitie

Table 1: Weighted Sample Statistics

\begin{tabular}{|c|c|c|c|c|c|}
\hline Variable & Weight & Mean & SD & Min & Max \\
\hline \multicolumn{6}{|l|}{ Variable of Interest } \\
\hline $\begin{array}{l}\text { Agricultural Production ( captured } \\
\text { by Log of Rice Production in tons }\end{array}$ & 92436.021 & 7.0767 & 2.561 & 3.401 & 11.578 \\
\hline \multicolumn{6}{|l|}{ Endogenous variable } \\
\hline $\begin{array}{l}\text { Adequate financing (captured by } \\
\text { credit/aid effectively used in } \\
\text { production) }\end{array}$ & 92436.021 & 0.042 & 0.201 & 0 & 1 \\
\hline \multicolumn{6}{|l|}{ Instruments for Endogenous Variable } \\
\hline Professional Association Network & 92436.021 & 0.037 & 0.088 & 0 & 1 \\
\hline Financial Institution availability & 92436.021 & 0.720 & 6.473 & 0 & 96 \\
\hline \multicolumn{6}{|l|}{ Exogenous Demographics } \\
\hline $\begin{array}{l}\text { Mother's education in years of } \\
\text { schooling }\end{array}$ & 92436.021 & 4.593 & 4.046 & 0 & 17 \\
\hline Mother's Age & 92436.021 & 28.495 & 6.975 & 15 & 49 \\
\hline $\begin{array}{l}\text { Agricultural Worker }(1=\text { mother } \\
\text { works' in agricultural sector, } 0 \text {, } \\
\text { otherwise) }\end{array}$ & 92436.021 & 0.620 & 0.142 & 0 & 1 \\
\hline $\begin{array}{l}\text { Gender of household head }(1= \\
\text { male, } 0 \text { otherwise })\end{array}$ & 92436.021 & 0.859 & 0.348 & 0 & 1 \\
\hline Family/Household size & 92436.021 & 10.212 & 5.599 & 1 & 43 \\
\hline Father/Paternal occupation & 92436.021 & 4.405 & 2.458 & 0 & 9 \\
\hline Ownership of Land Asset & 92436.021 & 0.010 & 0.099 & 0 & 1 \\
\hline Earnings from Agricultural activity & 92436.021 & 0.966 & 0.880 & 0 & 3 \\
\hline $\begin{array}{l}\text { Father/Paternal education in years } \\
\text { of schooling }\end{array}$ & 92436.021 & 5.056 & 4.871 & 0 & 17 \\
\hline Father/paternal Age & 92436.021 & 40.059 & 11.360 & 17 & 98 \\
\hline $\begin{array}{l}\text { Social status }(1=\text { nom poor, } 0 \text {, } \\
\text { otherwise }\end{array}$ & 92436.021 & 0.538 & 0.498 & 0 & 1 \\
\hline Size of Rice farm & 92436.021 & 0.010 & 0.019 & $1.00 \mathrm{e}-06$ & .08576 \\
\hline $\begin{array}{l}\text { Environmental characteristics } \\
\text { (Rainfall variations as average in } \\
\text { 2011) }\end{array}$ & 92436.021 & 369.784 & 199.95 & 216.356 & 941.081 \\
\hline $\begin{array}{l}\text { Geographical location of household } \\
\text { (1= urban, } 0 \text { otherwise) }\end{array}$ & 92436.021 & 0.394 & 0.488 & 0 & 1 \\
\hline \multicolumn{6}{|l|}{ Control Variables } \\
\hline Credit Residual $(\hat{R})$ & 92436.021 & $1.17 \mathrm{e}-10$ & 0.192 & -0.984 & 0.994 \\
\hline
\end{tabular}




\begin{tabular}{|l|l|l|l|l|l|}
\hline Credit x Credit Residual $(\hat{R})$ & 92436.021 & .036 & 0.179 & 0 & 0.994 \\
\hline Variables Identifying Types and Nature of Adequate Financing \\
\hline Personal Finance & 92436.0211 & 0.8643 & 0.2560 & 6000 & 9000 \\
\hline $\begin{array}{l}\text { Banks and Micro Financial } \\
\text { Institution }\end{array}$ & 92436.0211 & 0.5000 & 0.2386 & 0 & 950 \\
\hline Family and partner & 92436.0211 & 0.6359 & 0.4244 & 0 & 1700 \\
\hline Friends and Tontines & 92436.0211 & 0.063 & 0.1819 & 0 & 2300 \\
\hline Institutional Support & 92436.0211 & 0.045 & 0.3106 & 0 & 2300 \\
\hline Subsidies in Cash & 92436.0211 & 0.96931 & 0.63962 & 0 & 200 \\
\hline Subsidies in kind & 92436.0211 & 0.4016 & 0.35657 & 0 & 320 \\
\hline Total & \multicolumn{5}{|l|}{11391} \\
\hline
\end{tabular}

Source: Author $; \mathrm{SD}=$ Standard Deviation, $\min =$ minimum, $\max =$ maximum

The result of the descriptive statistics in table 2 shows that farmers received more financing in cash than in kind. This observation seem right in the sense that most banks and micro financial institutions deals more with finances than otherwise due to the nearness of these financial institutions to the farmers. One of the primary function of banks is lending so they are always available to give credit depending on the collateral security the farmers present. However, about 40.2 percent of agricultural financing is in kind, this probably should be originating from institutions such as the government through the ministry of agriculture and rural development, as well as other institutions like international organizations (World bank, ADB), this is usually the type of subsidies that is effectively use in agriculture.

Personal finance is up to 86.4 percent in terms of agricultural funding, especially in most interior villages where there are no banks most of the farmers does the financing by themselves, in addition to these; 50 percent of agricultural credit is from banks and micro financial institutions meaning that apart from banks there are other means of funding by cash. About 63.6 percent of agricultural support is from family members and partners, 6.3 percent from friends and tontines while 4.5 percent is from institutional support. All these means the individual farmers, family members and farmers' partners are the most frequent sponsors of agricultural activities in Cameroon.

\section{Determinants of Adequate Financing in Second-Generation Agriculture}

The result of table 3 , column one corresponding to first stage least square (FSLS) reveal that adequate financing in second generation agriculture is strongly determine by a number of factors; mother's age is an important contributing factor towards agricultural financing in Cameroon. Human being become more focus with age, especially when the pressure from family responsibility increases, people becomes more stable and objectively inclined in their performance. Focus on agriculture; we observed that it's very difficult to cultivate large plots of land without adequate use of finance. Aged mother's with the quest to satisfy their family by sending children to school and at the same time meeting other responsibilities at home, whenever they take credit, the effectively invest the money for the purpose in which it was borrowed. Many more age mothers have come to the consciousness of adequately investing in their farms either through hire labour, fertilizers, insecticide, pesticide and other farm inputs so as to not only satisfy the needs of their family but also the market.

The family/household size is a more motivating factor for adequate financing. The bigger the family size the greater their financial need. To meet these needs, households, especially those that depend on agricultural production are push to take credit from financial bodies for investment in their farms. Family size does not mean high labour supply, even when the labour supply increases; there is a great need to apply other farm inputs to increase productivity and the value chain agriculture. Rice production requires much land for cultivation and much farm inputs; this explains why ownership of land asset and the size of rice farm are positively correlating with adequate financing. The more rice farmers invest in their farms, the more likelihood that their produce will increase ceteris paribus, and those farmers with personal farms will need credit for other inputs while farmers with ownership of land will need credit to buy other farm inputs. This is particularly imperative with rice production in Cameroon.

Psychologically, the more an agricultural worker earns from his agricultural activity, the more they would want to earn the more; knowing that adequate financing is one of the principal way of increasing their farm products by effectively using the collected credit on their farms, most of them would like to take more credit and invest in their farms than 
elsewhere. The market for rice is among the most ready/fruitful markets internally and externally with a high demand. As seen in the literature, rice is among the most consumed cereal in Cameroon. Another interesting issue about adequate financing is that, non-poor households make more use of their finances or credit on their farms especially when the source of their wealth is from the farm. This explains why non-poor households are correlating with adequate financing.

Most agricultural professional association networks being initiative groups or associations are geared towards increasing agricultural production. This means that most of the credit received by these networks either in cash or in kind is effectively used in their farms to increase productivity; explaining why professional association networks is positively correlating with adequate financing. Agricultural credit financing is principally determined by the availability of financial institutions. These micro credit establishments equally provide to farmers advisory and supervisory services concerning the effective use of the credit they received. The activities of some banks, through the ministry of agriculture and rural development, C2D programmes (AFOP, ACEFA), local councils, NGOs, farmers associations and common initiative groups extend their services to the field to maximally ensure that the farmers are actually making good use of the credit in their agricultural activities.

Factors such as father's education, male gender, urban household location and rainfall characteristics are negatively correlating with adequate financing. This is possible in the sense that most educated people in Cameroon turn to stick to white collar jobs with less interest in agricultural activities, talk-less of rice production. So such people when they take credit they will prefer to use the credit on other things than otherwise. Male household head is also negatively correlating with adequate financing, in the sense that household heads in Cameroon have more responsibility than ever. The probability for them to use the credit collected for agricultural investment in other things (children education, family members business, other projects...) is very high. Urban household residence simply depicts the problem of substitution effect where by most farm credits are substituted for businesses and other opportunities while rainfall variation can either be an encouragement or a stumbling block to the credit collected. Extreme rain may reduce farmers' efforts in the use of farm inputs as every attempt to apply farm products will be defiled by the rain. Economically, this situation may act as a repelling effect in the use of adequate financing for agricultural production in Cameroon.

\section{Estimates of New Generation Agricultural Production Function}

The effect of adequate financing on agricultural production is estimated in table 3 using the ordinary least square; two stage least square instrumental variable and the control function respectively. The control function estimate helps to purge parameter estimates of simultaneity bias and heterogeneity concurrently. The OLS and TSLS are estimated under the assumption that: firstly the unobservable variables are uncorrelated with excluded instruments or that the correlation is linear and secondly that the estimation sample is randomly selected among households while the $\mathrm{CF}$ is estimated under the assumption that the sample on which agricultural production is estimated is non-random (Tambi, 2014). With regards to the result, the OLS shows that adequate financing is negatively influencing agricultural production to about 13.4 percent significant at 10 percent, however, the diagnostic tests of Durbin-Wu-Hausman Chi2 test for exogeneity of the potential endogenous variables [df: p-value] of 13.802[0.0002] shows that we rejects exogeneity of adequate financing in the agricultural production function indicating that the OLS is not a valid estimation method of our agricultural production function.

Considering the instrumental variable and control function results and checking for the validity and robustness of our result, we observed that in table 3, the weak identification test: Cragg-Donald F-Stat [5\% maximal IV relative bias] is 518.057[19.93], implies we reject the possibility that our instruments (professional association network and financial institution availability) are weak while the Sargan statistic (over-identification test of all instruments) of 0.602[0.4379] indicates that our instruments are relevant. Further, the coefficient of the predicted residual of adequate financing (coefficient $=-0.399 ; \mathrm{t}=-1.69$ ) in column 4 is statistically significant (though negative), confirming that this input into household asset endowments is indeed endogenous, so that inclusion of this residual term in the finance generating equation, as in above, is required for consistent estimation of structural parameters.

The TSLS and CF results are similar and reveal that adequate financing is strongly correlated with second-generation agricultural production with the IV estimate being 78 percent and CF being 78.2 percent respectively. We observed that, the control function result has a higher magnitude coefficient in both 
endogenous and exogenous determinants, meaning the TSLS results are understated and hence our preferred result to be reported in this study is the control function

Table 2: Estimates of Adequate Financing and Second-Generation Agricultural Production

\begin{tabular}{|c|c|c|c|c|}
\hline \multirow[t]{2}{*}{ Variable } & \multirow{2}{*}{$\begin{array}{l}\text { Adequate Financing } \\
\text { Reduced form }\end{array}$} & \multicolumn{3}{|c|}{ Agricultural Production Function } \\
\hline & & OLS & TSLS & $\mathrm{CF}$ \\
\hline Adequate financing & $\mathrm{n} / \mathrm{a}$ & $\begin{array}{l}-0.134 * \\
(-1.84)\end{array}$ & $\begin{array}{l}0.780 * * * \\
(3.02)\end{array}$ & $\begin{array}{l}0.782 * * * \\
(3.63)\end{array}$ \\
\hline Mother's education & $\begin{array}{l}0.0001 \\
(0.19)\end{array}$ & $\begin{array}{l}0.110 * * * \\
(20.54)\end{array}$ & $\begin{array}{l}0.109 * * * \\
(20.25)\end{array}$ & $\begin{array}{l}0.109 * * * \\
(20.44)\end{array}$ \\
\hline Mother's Age & $\begin{array}{l}0.001 * * * \\
(3.32)\end{array}$ & $\begin{array}{l}-0.011 * * * \\
(-4.60)\end{array}$ & $\begin{array}{l}-0.012 * * * \\
(-4.95)\end{array}$ & $\begin{array}{l}-0.011 * * * \\
(-4.71)\end{array}$ \\
\hline $\begin{array}{l}\text { Mother works' in } \\
\text { agriculture }\end{array}$ & $\begin{array}{l}-0.0003 \\
(-0.03)\end{array}$ & $\begin{array}{l}-0.019 * * \\
(-2.19)\end{array}$ & $\begin{array}{l}-0.020 \\
(-0.19)\end{array}$ & $\begin{array}{l}-0.017 \\
(-0.17)\end{array}$ \\
\hline Male household head & $\begin{array}{l}-0.0134 * * \\
(-2.54)\end{array}$ & $\begin{array}{l}-0.365^{* * *} \\
(-8.35)\end{array}$ & $\begin{array}{l}-0.354 * * * \\
(-8.04)\end{array}$ & $\begin{array}{l}-0.362 * * * \\
(-8.25)\end{array}$ \\
\hline Family size & $\begin{array}{l}0.0012 * * * \\
(3.64)\end{array}$ & $\begin{array}{l}0.028 * * * \\
(10.26)\end{array}$ & $\begin{array}{l}0.027 * * * \\
(9.82)\end{array}$ & $\begin{array}{l}0.028 * * * \\
(10.06)\end{array}$ \\
\hline Paternal occupation & $\begin{array}{l}0.0011 \\
(1.42)\end{array}$ & $\begin{array}{l}0.019 * * * \\
(3.20)\end{array}$ & $\begin{array}{l}0.018 * * * \\
(3.05)\end{array}$ & $\begin{array}{l}0.019 * * * \\
(3.13)\end{array}$ \\
\hline Ownership of Land Asset & $\begin{array}{l}0.1082^{* * * *} \\
(6.01)\end{array}$ & $\begin{array}{l}0.358 * * \\
(2.41)\end{array}$ & $\begin{array}{l}0.245 \\
(1.61)\end{array}$ & $\begin{array}{l}0.296^{*} \\
(1.93)\end{array}$ \\
\hline $\begin{array}{l}\text { Earnings from } \\
\text { Agricultural activity }\end{array}$ & $\begin{array}{l}0.0053 * * \\
(2.55)\end{array}$ & $\begin{array}{l}0.072 * * * \\
(4.19)\end{array}$ & $\begin{array}{l}0.068 * * * \\
(3.88)\end{array}$ & $\begin{array}{l}0.071 * * * \\
(4.10)\end{array}$ \\
\hline Paternal education & $\begin{array}{l}-0.0004 \\
(-0.87)\end{array}$ & $\begin{array}{l}0.011 * * * \\
(2.85)\end{array}$ & $\begin{array}{l}0.011 * * * \\
(2.94)\end{array}$ & $\begin{array}{l}0.011 * * * \\
(2.89)\end{array}$ \\
\hline Father/paternal Age & $\begin{array}{l}0.0001 \\
(0.30)\end{array}$ & $\begin{array}{l}0.010 * * * \\
(6.58)\end{array}$ & $\begin{array}{l}0.010 * * * \\
(6.44)\end{array}$ & $\begin{array}{l}0.010 * * * \\
(6.50)\end{array}$ \\
\hline non poor households & $\begin{array}{l}0.0121 * * \\
(2.24)\end{array}$ & $\begin{array}{l}0.456 * * * \\
(10.14)\end{array}$ & $\begin{array}{l}0.447 * * * \\
(9.86)\end{array}$ & $\begin{array}{l}0.4554 * * * \\
(10.06)\end{array}$ \\
\hline Size of Rice farm & $\begin{array}{l}0.6036^{* * * *} \\
(6.40)\end{array}$ & $\begin{array}{l}99.202 * * * \\
(126.83)\end{array}$ & $\begin{array}{l}99.759 * * * \\
(124.52)\end{array}$ & $\begin{array}{l}99.349 * * * \\
(120.93)\end{array}$ \\
\hline climate characteristics & $\begin{array}{l}-0.0000 * * * \\
(-3.67)\end{array}$ & $\begin{array}{l}0.001 * * * \\
(20.58)\end{array}$ & $\begin{array}{l}0.001 * * * \\
(20.78)\end{array}$ & $\begin{array}{l}0.001 * * * \\
(20.42)\end{array}$ \\
\hline Urban household & $\begin{array}{l}-0.0086^{*} \\
(-1.68)\end{array}$ & $\begin{array}{l}-0.532 * * * \\
(-12.55)\end{array}$ & $\begin{array}{l}-0.527 * * * \\
(-12.34)\end{array}$ & $\begin{array}{l}-0.531 * * * \\
(-12.51)\end{array}$ \\
\hline Constant & $\begin{array}{l}0.0119 \\
(1.07)\end{array}$ & $\begin{array}{l}4.536 * * * \\
(49.05)\end{array}$ & $\begin{array}{l}4.523 * * * \\
(48.59)\end{array}$ & $\begin{array}{l}4.533 * * * \\
(48.95)\end{array}$ \\
\hline $\begin{array}{l}\text { Professional Association } \\
\text { Network }\end{array}$ & $\begin{array}{l}0.0730^{* * * *} \\
(3.59)\end{array}$ & $\mathrm{n} / \mathrm{a}$ & $\mathrm{n} / \mathrm{a}$ & $\mathrm{n} / \mathrm{a}$ \\
\hline $\begin{array}{l}\text { Availability of Financial } \\
\text { Institution }\end{array}$ & $\begin{array}{l}0.0087 * * * \\
(31.95)\end{array}$ & $\mathrm{n} / \mathrm{a}$ & $\mathrm{n} / \mathrm{a}$ & $\mathrm{n} / \mathrm{a}$ \\
\hline Credit Residual ( $\hat{R})$ & $\mathrm{n} / \mathrm{a}$ & $\mathrm{n} / \mathrm{a}$ & $\mathrm{n} / \mathrm{a}$ & $\begin{array}{l}-0.399 \\
(-1.69)\end{array}$ \\
\hline Credit x Credit Residual & $\mathrm{n} / \mathrm{a}$ & $\mathrm{n} / \mathrm{a}$ & $\mathrm{n} / \mathrm{a}$ & $\begin{array}{l}-1.089 * * * \\
(-2.01)\end{array}$ \\
\hline$R^{2} /\left(\right.$ Pseudo- $\left.R^{2}\right)$ & 0.0934 & 0.6139 & 0.6088 & 0.6145 \\
\hline $\begin{array}{l}\text { F-Stat [df: p-val] ; Joint } \\
\text { F / } \chi^{2} \text { (p-value) test for } \\
\text { Но }\end{array}$ & $\begin{array}{l}75.40[16,11715 ; \\
0.0000]\end{array}$ & $\begin{array}{l}1241.83 \\
{[15,11716 ;} \\
0.0000]\end{array}$ & $\begin{array}{l}1225.91[15, \\
11716 ; \\
0.0000]\end{array}$ & $\begin{array}{l}1098.27 \\
{[17,11714 ;} \\
0.0000]\end{array}$ \\
\hline Cragg-Donald F-Stat & $\mathrm{n} / \mathrm{a}$ & $\mathrm{n} / \mathrm{a}$ & $518.057[19$. & $\mathrm{n} / \mathrm{a}$ \\
\hline
\end{tabular}




\begin{tabular}{|l|l|l|l|l|}
\hline & & & $93]$ & \\
\hline Sargan statistic test & $\mathrm{n} / \mathrm{a}$ & $\mathrm{n} / \mathrm{a}$ & $\begin{array}{l}0.602[0.437 \\
9]\end{array}$ & $\mathrm{n} / \mathrm{a}$ \\
\hline $\begin{array}{l}\text { Durbin-Wu- } \\
\text { Hausman } \chi_{\text {test }}^{2}\end{array}$ & $\mathrm{n} / \mathrm{a}$ & $\mathrm{n} / \mathrm{a}$ & $\begin{array}{l}13.802[0.00 \\
02]\end{array}$ & $\mathrm{n} / \mathrm{a}$ \\
\hline Number of Observations & & & \multicolumn{2}{|c|}{11391} \\
\hline
\end{tabular}

Source: Computed by author. ***, ** and *implies t-ratios indicating $1 \%, 5 \%$ and $10 \%$ levels of significance. $F S L S=$ First stage least square; $O L S=$ ordinary least square; $T S L S=$ two stage least square; $C F=$ Control Function; $n / a=$ not applicable

The 78.2 percent of the $\mathrm{CF}$ estimated effect of adequate financing on secondgeneration agricultural production means that whenever the farmers in Cameroon especially those in rice production uses effectively the credit obtained from financial institutions and other sources, agricultural production will increase by 78.2 percent. This estimated value means that for Cameroon to attain its 2035 emergency plan, more value should be place in agriculture as more than half of the working population in Cameroon work in this sector visà-vis adequate financing. Agricultural support/credit from personal finance, banks/micro financial institutions, aid from family/partners, friends/tontines, institutional support, subsidies in cash and subsidies in kind if effectively used in agricultural production can result to untold growth in the Cameroon economy.

Other determinants factors positive correlating with agricultural production include: mother's education in years of schooling, household size, paternal occupation, ownership of land asset, earnings from agricultural activity, paternal education in years of schooling, paternal age, social status, size of rice farm and environmental characteristics. Among these factors, we observed that size of rice farm and ownership of land asset have a greater magnitude as compare to other factors influencing second-generation agriculture in Cameroon. This simply means that, farmer's needs to extend the available land as well as buy more land if indeed they aspire to increase their agricultural production. More educated people also need to increase productivity; this can be seen with the high coefficient in mother's education in complete years of schooling. Training and education has been proven to be strongly affecting labour productivity implying that the more professional farmers engage in agriculture, the more they will rationally and rightfully make use of the credit they receive from donor institutions and hence improving on their productivity.

\section{Adequate Financing effect by Type and Nature of Agricultural Credit}

As indicated in table 4, personal finance plays a major role in the increase of agricultural production to about 11.7 percent, significant at one percent level. In terms of adequate financing, this result means that money from the farmers is often actually used to invest in the farms during every planting season to ensure further production. Principally, the first sponsor of agriculture is the farmer himself being in the buying of seeds for planting, clearing and hoeing of the farm, hiring of workers for harvesting as in the case of rice production. Most of the farms in rural Cameroon are located in the interior of villages, couple with the fact that the farmers are ignorant of the existence of assistance schemes, they end up not receiving any credit as individuals except when there is exclusive community assistance from the Ministry of Agriculture and Rural Development (MINADER), local and International NGOs or any other based organization.

Personal funding reveals commitment and interest in production, owing to Cameroon second-generation agriculture; there have been a mass campaign from MINADER towards the mechanization of agriculture in other to add real value to obtain mass production and alleviate poverty as well as the food security problem. It should be noted that most of the personal financing is from common initiative groups (CIG), associations and producer cooperatives. The producer cooperative simply refers to people engaged in production in one or separate enterprises, whether these are farms, fishing boats, forests, artist studios, or craft workshops. The co-operative members may even be independent producers. They may buy farm inputs, equipment, and insurance, hire managers and sales people, market and advertise together or operate storage or processing facilities or a distribution network. 
Table 4: Estimates of Adequate Financing by Type and Nature of Agricultural Credit

\begin{tabular}{|c|c|c|c|c|c|c|c|}
\hline \multirow[t]{2}{*}{ Variable } & \multicolumn{7}{|c|}{ Estimation Method: Control Function } \\
\hline & PF & BMFI & FP & FT & IS & SC & SK \\
\hline $\begin{array}{l}\text { Adequate } \\
\text { financing }\end{array}$ & $\begin{array}{l}0.117^{\text {**** }} \\
(3.29)\end{array}$ & $\begin{array}{l}0.273^{\text {*** }} \\
(3.38)\end{array}$ & $\begin{array}{l}0.313^{\text {*** }} \\
(3.27)\end{array}$ & $\begin{array}{l}0.231^{\text {*** }} \\
(3.60)\end{array}$ & $\begin{array}{l}0.155^{* *} \\
(2.52)\end{array}$ & $\begin{array}{l}0.403 \\
(1.14)\end{array}$ & $\begin{array}{l}0.530^{* * *} \\
(3.32)\end{array}$ \\
\hline $\begin{array}{l}\text { Mother's } \\
\text { education }\end{array}$ & $\begin{array}{l}0.109^{* * *} \\
(20.52)\end{array}$ & $\begin{array}{l}0.112^{* * *} \\
(19.01)\end{array}$ & $\begin{array}{l}0.115^{\text {*** }} \\
(17.81)\end{array}$ & $\begin{array}{l}0.098^{* * *} \\
(17.40)\end{array}$ & $\begin{array}{l}0.008^{* * *} \\
(8.73)\end{array}$ & $\begin{array}{l}0.054^{* * *} \\
(12.09)\end{array}$ & $\begin{array}{l}0.095^{* * *} \\
(11.68)\end{array}$ \\
\hline Mother's Age & $\begin{array}{l}-0.011^{\text {*** }} \\
(-4.65)\end{array}$ & $\begin{array}{l}-0.011^{* * *} \\
(-4.26)\end{array}$ & $\begin{array}{l}-0.011^{* * *} \\
(-4.17)\end{array}$ & $\begin{array}{l}-0.014^{* * *} \\
(-5.39)\end{array}$ & $\begin{array}{l}-0.000 \\
(-0.85)\end{array}$ & $\begin{array}{l}-0.005^{\text {*** }} \\
(2.97)\end{array}$ & $\begin{array}{l}0.014^{* * *} \\
(-4.35)\end{array}$ \\
\hline $\begin{array}{l}\text { Mother works' } \\
\text { in agriculture }\end{array}$ & $\begin{array}{l}0.206^{* *} \\
(2.13)\end{array}$ & $\begin{array}{l}0.186^{*} \\
(1.77)\end{array}$ & $\begin{array}{l}0.188^{*} \\
(1.70)\end{array}$ & $\begin{array}{l}0.234^{* *} \\
(2.34)\end{array}$ & $\begin{array}{l}0.014 \\
(1.01)\end{array}$ & $\begin{array}{l}0.213 * * * \\
(-2.67)\end{array}$ & $\begin{array}{l}0.248^{*} \\
(1.85)\end{array}$ \\
\hline Male HH head & $\begin{array}{l}-0.358^{\text {*** }} \\
(-8.17)\end{array}$ & $\begin{array}{l}-0.391^{* * *} \\
(-8.16)\end{array}$ & $\begin{array}{l}-0.415^{* * *} \\
(-8.15)\end{array}$ & $\begin{array}{l}-0.297^{\text {*** }} \\
(-6.32)\end{array}$ & $\begin{array}{l}-0.001 \\
(-0.15)\end{array}$ & $\begin{array}{l}-0.283^{* * *} \\
(-7.78)\end{array}$ & $\begin{array}{l}-0.352^{* * *} \\
(-5.42)\end{array}$ \\
\hline Family/HH size & $\begin{array}{l}0.028^{* * *} \\
(10.13)\end{array}$ & $\begin{array}{l}0.031^{* * *} \\
(10.31)\end{array}$ & $\begin{array}{l}0.031^{* * *} \\
(10.21)\end{array}$ & $\begin{array}{l}0.033^{* * *} \\
(11.51)\end{array}$ & $\begin{array}{l}-0.002^{* * *} \\
(-5.04)\end{array}$ & $\begin{array}{l}-0.001 \\
(-0.81)\end{array}$ & $\begin{array}{l}0.041^{* * *} \\
(11.21)\end{array}$ \\
\hline $\begin{array}{l}\text { Paternal } \\
\text { occupation }\end{array}$ & $\begin{array}{l}0.018^{* * *} \\
(2.91)\end{array}$ & $\begin{array}{l}0.018^{* * *} \\
(2.74)\end{array}$ & $\begin{array}{l}0.02^{* * *} \\
(2.78)\end{array}$ & $\begin{array}{l}0.025^{* * *} \\
(3.86)\end{array}$ & $\begin{array}{l}-0.001^{* *} \\
(-2.05)\end{array}$ & $\begin{array}{l}-0.007 \\
(-1.58)\end{array}$ & $\begin{array}{l}0.036^{* * *} \\
(4.04)\end{array}$ \\
\hline $\begin{array}{l}\text { HH Ownership } \\
\text { of Land Asset }\end{array}$ & $\begin{array}{l}0.018 \\
(1.21)\end{array}$ & $\begin{array}{l}0.016 \\
(0.99)\end{array}$ & $\begin{array}{l}0.015 \\
(0.86)\end{array}$ & $\begin{array}{l}0.025 \\
(1.58)\end{array}$ & $\begin{array}{l}-0.003 \\
(-1.27)\end{array}$ & $\begin{array}{l}0.023 \\
(1.63)\end{array}$ & $\begin{array}{l}0.022 \\
(1.06)\end{array}$ \\
\hline $\begin{array}{l}\text { HH Agricultural } \\
\text { Earning }\end{array}$ & $\begin{array}{l}0.073^{* * *} \\
(4.13)\end{array}$ & $\begin{array}{l}0.075^{* * *} \\
(4.08)\end{array}$ & $\begin{array}{l}0.076^{\text {*** }} \\
(3.89)\end{array}$ & $\begin{array}{l}0.095^{\text {*** }} \\
(5.19)\end{array}$ & $\begin{array}{l}-0.016^{* * *} \\
(-5.06)\end{array}$ & $\begin{array}{l}0.061^{* * *} \\
(4.67)\end{array}$ & $\begin{array}{l}0.101^{* * *} \\
(4.27)\end{array}$ \\
\hline $\begin{array}{l}\text { Paternal } \\
\text { education }\end{array}$ & $\begin{array}{l}0.011^{* * *} \\
(3.04)\end{array}$ & $\begin{array}{l}0.011^{\text {*** }} \\
(2.63)\end{array}$ & $\begin{array}{l}0.011^{* *} \\
(2.49)\end{array}$ & $\begin{array}{l}0.017^{* * *} \\
(4.18)\end{array}$ & $\begin{array}{l}-0.001^{* * *} \\
(-3.20)\end{array}$ & $\begin{array}{l}0.015^{* * *} \\
(4.93)\end{array}$ & $\begin{array}{l}0.020^{* * *} \\
(3.55)\end{array}$ \\
\hline $\begin{array}{l}\text { Father/paternal } \\
\text { Age }\end{array}$ & $\begin{array}{l}0.010^{* * *} \\
(6.40)\end{array}$ & $\begin{array}{l}0.010^{* * *} \\
(6.33)\end{array}$ & $\begin{array}{l}0.011^{* * *} \\
(6.29)\end{array}$ & $\begin{array}{l}0.009^{* * *} \\
(6.12)\end{array}$ & $\begin{array}{l}-0.000 \\
(0.105)\end{array}$ & $\begin{array}{l}0.002^{*} \\
(1.92)\end{array}$ & $\begin{array}{l}0.011^{* * *} \\
(5.51)\end{array}$ \\
\hline Non poor $\mathrm{HH}$ & $\begin{array}{l}0.456^{\text {*** }} \\
(10.08)\end{array}$ & $\begin{array}{l}0.428^{* * *} \\
(9.16)\end{array}$ & $\begin{array}{l}0.424^{* * *} \\
(8.37)\end{array}$ & $\begin{array}{l}0.544^{* * *} \\
(11.36)\end{array}$ & $\begin{array}{l}0.016^{* *} \\
(2.42)\end{array}$ & $\begin{array}{l}0.588^{* * *} \\
(14.88)\end{array}$ & $\begin{array}{l}0.504^{* * *} \\
(7.90)\end{array}$ \\
\hline $\begin{array}{l}\text { HH Size of Rice } \\
\text { farm }\end{array}$ & $\begin{array}{l}99.382^{\text {*** }} \\
(121.12)\end{array}$ & $\begin{array}{l}100.1^{* * *} \\
(117.17)\end{array}$ & $\begin{array}{l}100.35^{* * * *} \\
(112.49)\end{array}$ & $\begin{array}{l}101.12^{\text {*** }} \\
(121.73)\end{array}$ & $\begin{array}{l}336.7^{* * * *} \\
(434.67)\end{array}$ & $\begin{array}{l}87.048^{* * *} \\
(172.98)\end{array}$ & $\begin{array}{l}103.7^{* * *} \\
(101.77)\end{array}$ \\
\hline $\begin{array}{l}\text { Rainfall } \\
\text { Variation }\end{array}$ & $\begin{array}{l}0.001^{\text {*** }} \\
(20.46)\end{array}$ & $\begin{array}{l}0.002^{* * *} \\
(19.95)\end{array}$ & $\begin{array}{l}0.001^{* * *} \\
(18.69)\end{array}$ & $\begin{array}{l}0.001^{* * *} \\
(17.05)\end{array}$ & $\begin{array}{l}-0.007^{* * *} \\
(-241.69)\end{array}$ & $\begin{array}{l}0.003^{* * *} \\
(67.35)\end{array}$ & $\begin{array}{l}0.001^{* * *} \\
(15.10)\end{array}$ \\
\hline $\begin{array}{l}\text { HH Urban } \\
\text { location }\end{array}$ & $\begin{array}{l}-0.536^{* * * *} \\
(-12.62)\end{array}$ & $\begin{array}{l}-0.604^{* * *} \\
(-13.45)\end{array}$ & $\begin{array}{l}-0.616^{* * *} \\
(-12.70)\end{array}$ & $\begin{array}{l}-0.486^{\text {**** }} \\
(-10.87)\end{array}$ & $\begin{array}{l}0.141^{* * *} \\
(22.78)\end{array}$ & $\begin{array}{l}-0.746^{* * *} \\
(-19.83)\end{array}$ & $\begin{array}{l}-0.618^{* * *} \\
(-10.17)\end{array}$ \\
\hline Credit Residual & $\begin{array}{l}-0.474 \\
(-1.10)\end{array}$ & $\begin{array}{l}-0.617 \\
(-1.31)\end{array}$ & $\begin{array}{l}-0.662 \\
(-1.26)\end{array}$ & $\begin{array}{l}-0.481 \\
(-1.07)\end{array}$ & $\begin{array}{l}0.046 \\
(0.77)\end{array}$ & $\begin{array}{l}0.622 \\
(1.36)\end{array}$ & $\begin{array}{l}-0.895 \\
(-1.46)\end{array}$ \\
\hline Credit x $\hat{R}_{C R}$ & $\begin{array}{l}-1.012^{*} \\
(-1.72)\end{array}$ & $\begin{array}{l}-1.052 \\
(-1.62)\end{array}$ & $\begin{array}{l}-1.074 \\
(-1.52)\end{array}$ & $\begin{array}{l}-1.091^{*} \\
(-1.80)\end{array}$ & $\begin{array}{l}-0.223^{* *} \\
(-2.40)\end{array}$ & $\begin{array}{l}-1.180^{*} \\
(-1.93)\end{array}$ & $\begin{array}{l}-1.032 \\
(-1.26)\end{array}$ \\
\hline Constant & $\begin{array}{l}4.5^{\text {*** }} \\
(47.68)\end{array}$ & $\begin{array}{l}4.451^{* * *} \\
(47.68)\end{array}$ & $\begin{array}{l}4.425^{\text {*** }} \\
(41.69)\end{array}$ & $\begin{array}{l}4.337^{* * *} \\
(43.89)\end{array}$ & $\begin{array}{l}9.267^{* * * *} \\
(484.67)\end{array}$ & $\begin{array}{l}2.973^{* * *} \\
(42.27)\end{array}$ & $\begin{array}{l}4.040^{* * *} \\
(30.71)\end{array}$ \\
\hline $\begin{array}{l}R^{2} /(\text { Pseudo- } \\
\left.R^{2}\right)\end{array}$ & 0.6147 & 0.6147 & 0.6197 & 0.6369 & 0.9871 & 0.9371 & 0.6458 \\
\hline $\begin{array}{l}\text { F-Stat [df: p- } \\
\text { val] }\end{array}$ & $\begin{array}{l}1099.16 \\
{[17,} \\
11714 ; 0 . \\
0000]\end{array}$ & $\begin{array}{l}1047.45 \\
{[17,} \\
10991 ; 0 . \\
0000]\end{array}$ & $\begin{array}{l}988.66 \\
{[17} \\
10314 ; \\
0.0000]\end{array}$ & $\begin{array}{l}1106.84 \\
{[17} \\
10728 ; \\
0.0000]\end{array}$ & $\begin{array}{l}18185.06 \\
{[7,4049 ;} \\
0.0000]\end{array}$ & $\begin{array}{l}4041.64 \\
{[17,} \\
4614 ; \\
0.0000]\end{array}$ & $\begin{array}{l}815.19 \\
{[17,} \\
7600 ; \\
0.0000]\end{array}$ \\
\hline Observation & 11391 & 11009 & 10332 & 10746 & 4067 & 4632 & 7618 \\
\hline
\end{tabular}

Source: Computed by author; Notes: $(\bullet)$ implies t-ratios. $* * *, * *$ and $*$ indicate $1 \%, 5 \%$ and $10 \%$ levels of significance, respectively. $\mathrm{HH}=$ Households. $P F=$ Personal Finance; BMFI= Banks and Micro

Financial Institutions; FP= Family and partner; FT= Friends and Tontine; IS= Institutional Support; $S C=$ Subsidies in Cash; $S K=$ Subsidies in kind

Credits from banks and micro financial institutions as per our result, strongly influence agricultural production to about 23.3 percent, significant at one level vis-a-vis adequate financing. Farmers are practically conscious of the interest rate attributed to loans and credit from banks and micro financial institutions and so they are always ready to adequately use the money to invest in their farms to make some benefits in preparation for pay back. With this mentality, farmers put all the precaution in place, even when they are not actually followup, they do their possible best to adequately invest in their farms except otherwise. All these 
means that the farmers that receive credit from the banks and micro financial institutions are motivated to judiciously use the credit to invest in their farms because of the payment of the interest rate attributed to the credit and the payment of the principal. This simply implies the payback period is a strong catalyst of agricultural growth and productivity in general.

As a tool to modernizing agriculture, in 2013 Cameroon launch the creation of a new bank known as Cameroon Agriculture Financial Rural Corporation (CAFRUC) whose mission is to contribute to the financing of agricultural projects. The creation of CAFRUC is to fill the void left by Crédit Agricole of Cameroon, the Cameroon Development Bank (CDB), and the National Fund for Rural Development (FONADER) or the Guarantee Fund for Small Business (FOGAPE) who among other mission is to contribute to the financing of agro-pastoral activities. These financial institutions failed because of mismanagement and economic austerity policies imposed by the Bretton Woods institutions (GOC, 2013). The creation of a bank intended primarily to finance agriculture could reduce imports, through a revival of domestic production, couple with the decision to take a number of measures aimed at customs tax exemption and tax-free consumer products.

Agricultural aid from family and partners increases agricultural production to about 31.3 percent significant at one percent degree level vis-a-vis adequate financing. This simply reveal that there is no aid in agricultural production that is useless, family members and partners can play a major role in increasing agricultural production, either in cash or in kind. Most often aid from closed relatives may require much follow-up and questioning to know how the crops and plants in general are growing in the farm. To avoid embarrassment, most farmers end up absolutely investing in their agricultural activities and hence increasing production. Agricultural aid from friends and credits from tontines can increase agricultural production to about 23.1 percent significant at one percent vis-a-vis adequate financing. Tontine is like the personal savings of the farmers themselves. Hence this money can be invested in production without any fear of payback, it's equally recorded over the years that farmers decide to earn this money only when they speculate to invest it or solve a particular problem. Friends in one way or the other in cash or in kind may provide assistance that can boost the agricultural sector.

The government through the ministry of agriculture and rural development, French Cooperation, German Cooperation, Food and
Agricultural Organization, United Nations Development Assistance Framework (UNDAF), International Fund for Agricultural Development (IFAD) and the European Union (EU) are the principal institutions supporting agricultural production in Cameroon. In association to credit from financial institutions, these institutions give both financial and nonfinancial support to agricultural households, on the basis of our result, the role played by these structures is relatively important in augmenting agricultural productivity in Cameroon. Other factors influencing institutional support to agricultural production are educational status, farm size, social status and urban location. Generally, the larger the farm sizes the higher the possibility of gaining support from the government and other institutional support. Our result reveals that non poor households are more prone to receiving support than otherwise, it's the same with educated households. Larger farm size also serves as a security to receiving finance as the aim of this institution is to alleviate poverty and the food security problem.

This is one of the most interesting results in the sense that, subsidies in cash is not associated with adequate financing in terms of agricultural productivity. This means that when farmers received finance in the form of cash they hardly invest this money in their farms and hence subsidies in the form of cash do not affect agriculture in any way. A subsidy in kind is positively and strongly affecting agricultural production to about 53 percent at a significant level of one percent. The magnitude of this result is stronger than those of the others meaning that any element of assistant in terms of kind is invested in the farm and this goes a long way to increase productivity as to otherwise. Unfortunately, our descriptive statistics shows that most of the support/aid/credit given in the agricultural sector is more in cash to about 96 percent but ironically a chunk of the money ends elsewhere than the purpose for which it was given.

\section{Conclusion}

This study is captured 'Response to second-generation agriculture: quantifying the effects of adequate financing on agricultural production in Cameroon'. Food insecurity, malnutrition and hunger are persistent within the urban and rural areas in Cameroon. This situation is not due to the lack of food, but to poor systems for regulating the access to food resulting from inadequate development policy approaches. As a step to solve this problem, our study seek to: (1) evaluate the impact of adequate financing on agricultural production, (2) explore the determinants of adequate 
financing in second-generation agriculture, (3) examine adequate financing effect by type and nature of agricultural credit and (4) to derived policy implications on the bases of our analysis.

In terms of variables and Methodology: (1) agricultural production is capture by $\log$ of rice production; (2) the potential endogenous variable is adequate financing capture by credit effectively used in agricultural production; (3) potential exogenous demographics are: mother education and age, place of residence, household size, gender of household head, household social status, occupation of household; farm size, level of expected Income from agriculture, rainfall characteristics and belonging to a professional network. The instrument for endogenous variable is: availability of financial institutions and professional network. We estimate the OLS, 2SLS and Control Function using STATA 14.0. With the Control function estimate being our preferred result since it helps to purge parameter estimates of simultaneity bias and heterogeneity concurrently.

The first stage least square result reveal that earnings from agriculture, farm size, mother's age, existence of professional network, availability of financial institutions, non-poor households and family size are important contributing factors to agricultural financing in terms of adequate financing in second generation agriculture in Cameroon. While the control function result shows that adequate financing is strongly correlated with secondgeneration agricultural production meaning that whenever the farmers in Cameroon especially those in rice production uses effectively the credit obtained from financial institutions and other sources, agricultural production will increase by 78.2 percent. Results by type and nature of agricultural credit show that agricultural credit/aid from personal funding, bank and micro-financial institution, family and partners, fiends and tontines and institutional support increases agricultural productivity. However, subsidies in kind play a major role in augmenting agricultural production as compare to subsidies in cash.

These results have implications for addressing the food security problem and poverty reduction in terms of improving agricultural productivity through adequate financing and subsidies in kind, income growth and redistribution in this period of economic emergence.

\section{References}

African Development Bank (ADB) (2010) Agro-value chain analysis and development: a staff working paper
Ajakaiye O and Mwabu G (2007): The Demand for Reproductive Health Services: An Application of Control Function Approach. Frameworks of analysis, issued as a framework paper for the Collaborative Project on Reproductive Health, Economic Growth and Poverty Reduction in Africa, AERC, Nairobi.

AfDB (2010): The African Development Bank and Cameroon - forty years of partnership; Bank Group Ongoing Operations in Cameroon, as at $10 / 2 / 2010$ (in UA)

Business Cameroon (2006): Cameroon online business centre, January, 2006

Bound J, Schoenbaum M, Stinebrickner T and Waidmann T (1995): "The dynamic effects of health on the labor force transitions of older workers", Labour Economics, 6, 179-202.

Card D (2001); Estimating the Return to Schooling: Progress on Some Persistent Econometric Problems. Econometrica, Vol. 69(5): 1127-1160.

Cebu Study Team (1982): A child health production function estimated from longitudinal data. Journal of Development Economics: 38(2):323-51.

FAO (2006): Food and Agricultural Organizations Statistics. 2012. available at: www.faostat.fao.org/

Garen J (1984): The Returns to Schooling: A Selectivity Bias Approach with a Continuous Choice Variable. Econometrica, Vol. 52(5): 1199-1218

Government of Cameroon (GOC) (2011): Government of Cameroon, global gender gap - country profile report, 2011. $23^{\text {rd }}$ September, 2011.

GOC (2013): Government of Cameroon Business in Cameroon, June 2015 Yaounde

IRRI (2007): International Rice Research Institute - Annual Report. International rice research, Page 217

INS (2002): National Institute of statistics Poverty Profile in Rural Areas: Second Cameroon Household Survey, December 2002

Ministry of Agriculture and rural development, Grassfield Participatory and decentralized Rural development project, Progress Report, December 2007

Molua, E (2010): Response of Rice Yields in Cameroon: Some Implications for Agricultural Price Policy. Libyan Agriculture Research Center Journal International 1 (3): 182-194, 2010 
Mwabu G (2009): The Production of Child Health in Kenya: A Structural Model of Birth Weight. Journal of African Economies, Vol. 18(2): 212-260.

Rivers D and Vuong Q (1988): Limited information estimators and exogeneity tests for simultaneous probit models, Journal of Econometrics 39 (1988) 347366. North-Holland

Rosenzweig M, and Schultz T (1983): Estimating a Household Production Function: Heterogeneity, the Demand for Health Inputs, and Their Effects of Birth Weight, Journal of Political Economy, vol. 91(50: 723-746.
Strauss J and Thomas D (1998): Health, Nutrition, and Economic Development: Journal of Economic Literature, Vol. 36(2): 766-817.

Tambi D M (2014): Modeling the effects of Mother's Age at first birth on child health at birth. Asian Journal of Economic Modelling, 2014, 2(1): 1-17

Wooldridge J (1997): On Two Stage Least Squares Estimation of the Average Treatment Effect in a Random Coefficient Model. Economics Letters, Vol. 56: 129-133.

Wooldridge J, (2002): Econometric Analysis of Cross Section and Panel Data, MA: MIT Press, Cambridge. 